\title{
椎骨動脈解離による頸髄梗塞
}

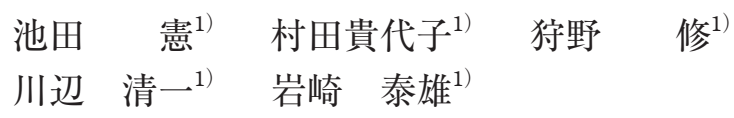

\section{Cervical cord infarction due to dissection of the vertebral artery}

Ken Ikeda, M.D., Ph.D. ${ }^{1}{ }^{*}$, Kiyoko Murata, M.D. ${ }^{1)}$, Osamu Kano, M.D. ${ }^{1}$, Kiyokazu Kawabe, M.D. ${ }^{1)}$ and Yasuo Iwasaki, M.D. ${ }^{1)}$

${ }^{1)}$ Department of Neurology, Toho University Omori Medical Center

(臨床神経 2014;54:831-832)

2014 年 3 月 6 日

帱啓

本誌 54 巻 2 号に掲載されました「ゴルフによる一側椎骨動 脈解離が原因となった頸髄梗塞の 1 例」を帱読しました。こ の論文で徳元ら ${ }^{1)}$ は右椎骨動脈解離により両側前角部の頸髄 梗塞を発症した貴重な症例を報告されています。私どもも一 側椎骨動脈解離による両側後脊髄梗塞を呈した症例を報告し ています ${ }^{2)}$ ，今回，一側椎骨動脈解離による頸䯣梗塞の発症 機序と診断契機について述べさせていただきたく，この筆を 取りました。

私どもの症例は 63 歳女性で既往に喫煙と高血圧があり，歯 科処置のために頸部を伸展した姿勢を 1 時間ほど保持した後 に項部，両側の肩と上肢にしびれ，両下肢の脱力を自覚しま した. 2 週間後の神経学的診察で両下肢の深部感覚障害, 痤 性対麻疩，小脳失調，直腸・膀胱障害をみとめました。頸髄 MRI でC4 から C7 レベルに両側の後索ないし側索に $\mathrm{T}_{2}$ 高信 号域が描出されました。C4 と C5 レベルの後索の一部に造影 効果をみとめました。軸状断 $\mathrm{T}_{1}$ 強調像では $\mathrm{C} 3$ から $\mathrm{C} 5$ レ心゙ ルの右椎骨動脈の flow void sign に着目したところ血管腔の 狭窄と血管壁の一部に高信号域が確認されました。本症例の 画像所見において, $\mathrm{T}_{2}$ 強調像や造影 MRIでは脱髄, 腫瘍, 脊 髄炎と梗塞巣との鑑別は困難でした。よって, 脊髄梗塞の診 断の決めてとなった要点は頸部伸展位を長時間保持した病歴 と $\mathrm{T}_{1}$ 強調像の右椎骨動脈壁の高信号域に気付くことでした. 德元ら ${ }^{1)}$ とわれわれの症例 ${ }^{2)}$ の共通点は, 病歴で血管危険因 子に高血圧があり, 頸部の姿勢保持や運動直後に項部痛やし びれ，両肩や両下肢に脱力感を突然自覚しています。画像所 見では頸髄の $\mathrm{T}_{2}$ 高信号域に加えて, 軸状断 $\mathrm{T}_{1}$ 強調像で右椎
骨動脈の異常に気付いた点が診断にいたる経緯でした。

徳元ら ${ }^{1)}$ は椎骨動脈解離による頸髄梗塞をきたした 11 例を Table 2 に要約しています。この記載に加えて Pryse-Philips ${ }^{3)}$ と福田ら ${ }^{4}$ が一側椎骨動脈解離による後脊髄梗塞を報告して います.われわれの症例とこの 2 症例を加えた合計 14 例を検 討すると, 椎骨動脈解離は 1 例を除いて一側です, 病巣の局 在分布に関しては前脊䯣 5 例, 後脊髄 8 例, 左脊髄 1 例です. 脊髄梗塞巣と椎骨動脈解離の位置関倸は両側 7 例, 病側 7 例 です，脊䯣動脈の解剖は正中部に 1 本の前脊䯣動脈が左右前 角部に分布しています。後脊䯣動脈は左右 2 本が存在し，血 管網や吻合が豊富であると周知されています。しかし，一側 椎骨動脈解離で両側前脊䯣動脈域に梗塞巣が生じる機序は, この解剖学的特徵に加えて, 徳元ら ${ }^{1)}$ は前根動脈や前脊髄動 脈の椎骨動脈からの起源に左右優位側が存在することを考察 しています。一側椎骨動脈解離による後脊髄動脈梗塞におい ても $2 / 8$ 例 (25\%) で両側に梗塞巣が発症しています。この 点から後脊髄動脈域の血流支配にも椎骨動脈からの左右優位 性起源があり, 左右の後脊髄動脈間の吻合枝が少ない症例の 存在が示唆されます。

MRI が普及した現況においても脊髄梗塞の診断が困難な 要因は, 頸部の姿勢や運動の詳細な病歴聴取が見落とされて いる可能性があります。脊髄梗塞の画像診断においては前脊 髄梗塞に特徵的な両側前角に $\mathrm{T}_{2}$ 高信号域が出現するフクロ ウの目徵候以外では, 脱随巣や腫瘍との鑑別が困難です、画 像所見の最重要点は軸状断 $\mathrm{T}_{1}$ 強調像で椎骨動脈の著明な左 右差や狭窄の有無, 血管壁の高信号域に着目して, 頸部 MRA や 3D-CTA で同動脈の精査を進めることです。これまでに動 脈解離による脊髄梗塞の報告例は少数です。しかし，今後は

\footnotetext{
*Corresponding author: 東邦大学医療センター大森病院神経内科〔† 143-8541 東京都大田区大森西 6-11-1〕

1) 東邦大学医療センター大森病院神経内科

(受付日：2014 年 3 月 7 日)
} 
脊髄疾患を診療する神経内科や脳神経外科, 整形外科の医師 が頸部姿勢や動作の詳細な病歴聴取と $\mathrm{T}_{1}$ 強調像で椎骨動脈 の異常に細心の注意を払えば，迅速な診断と早期治療が可能 となる点を強調したく存じます。

\section{敬具}

※本論文に関連し，開示すべきCOI 状態にある企業，組織，団体 はいずれも有りません。

\section{文献}

1）徳元一樹, 上田進彦.ゴルフによる一側椎骨動脈解離が原 因となった頸髄梗塞の 1 例。臨床神経 2014;54:151-157.

2) Murata K, Ikeda K, Muto M, et al. A case of posterior spinal artery syndrome in the cervical cord: a review of the clinicoradiological literature. Intern Med 2012;51:803-807.

3) Pryse-Philips W. Infarction of the medulla and cervical cord after fitness exercises. Stroke 1989;20:292-294.

4）福田 準，木谷光博，椎骨動脈閉塞により発症した高位頚髄 の片側後脊髄動脈領域梗塞の 1 例。臨床神経 1994;34:11711174 . 